\title{
UTILISATION OF SATELLITE DATA IN IDENTIFICATION OF GEOMORPHIC LANDFORM AND ITS ROLE IN ARSENIC RELEASE IN GROUNDWATER.
}

\author{
R. P. Singh ${ }^{*}$, N. Singh ${ }^{\text {a }}$, S. Shashtri ${ }^{a}$, S. Mukherjee ${ }^{a}$ \\ ${ }^{a}$ School of Environmental Sciences, Jawaharlal Nehru University New Delhi 110067 - (singhravi004, hereisneha.singh, sn.shashtri, \\ saumitramukherjee3)@gmail.com
}

KEY WORDS: Geomorphology, GIS, Groundwater, Arsenic, Slope,

\begin{abstract}
:
The present study was conducted to explore the influence of geomorphic features of the area on the mobilization of arsenic in groundwater. In this study, remote sensing and GIS techniques were used to prepare the geomorphic and slope map of the area. Different geomorphic features were identified on the basis of spectral signature on the LISS III and Landsat satellite image and field survey. Groundwater samples were collected from each representative geomorphic feature to inspect the arsenic contamination in the area. The study area is drained by the Brahmaputra river and its tributaries and contain mainly fluvial geomorphic units especially older flood plain, palaeochannels, oxbow lakes, channel islands; and hilly areas at some of the places. In this study it was observed that enrichment of arsenic in groundwater varies along the geomorphic units in following trends Paleochannel> Younger alluvial plain $>$ Active flood plain $>$ channel island $>$ dissected hills. The above trend shows that a higher concentration of arsenic is found in the groundwater samples collected from the fluvial landforms as compared to those collected from structural landforms. Brahmaputra River and its tributaries carry the sediment load from the Himalayan foothills, which get deposited in these features during the lateral shift of the river's courses. Arsenic bearing minerals may get transported through river and deposit in the geomorphological features along with organic matter. The flat terrain of the area as seen from the slope map provides more residence time to water to infiltrate into the aquifer. The microbial degradation of organic matter generates the reducing environment and facilitates the dissolution of iron hydroxide thus releasing the adsorbed arsenic into the groundwater.
\end{abstract}

\section{INTRODUCTION}

Contamination of drinking water is an environmental challenge which has affected the livelihood of millions of population.( Gaus et al.,2003) Arsenic problem is common to several alluvial plains of South and East Asia as it has been reported in many fluvio-deltaic tracts of the world like Hanoi City and the upper end of Red River Delta (Berg et al., 2001), Tarai belt of Nepal (Gurung et al., 2005), Indus delta of Pakistan (Khan et al., 2010), delta plains of the Mekong river in Cambodia (Polya et al., 2005). In India arsenic enrichment in groundwater has been reported in the Ganga-Brahmaputra river plain (Das et al., 1996) and a number of studies have been conducted in West Bengal and Bangladesh related to the arsenic mobilization in groundwater and its correlation with other affecting parameters (Mukherjee et al., 2005; McArthur et al., 2001; Nickson et al., 2000; Chowdhury et al., 1999; Chakraborti et al., 1996). Continuous exposure to arsenic contaminated groundwater may cause conjunctivitis, hyper pigmentation, painful skin blisters on human body even causing gangrene of the limbs, and the skin cancer.

Regional occurrence of arsenic in West Bengal and Bangladesh is mostly attributed to the geogenic source which releases the arsenic in groundwater through natural hydrochemical processes occurring in the study area (Nickson et al., 2000; Bhattacharya et al., 1997). There are several hypotheses regarding the enhanced concentration of arsenic in groundwater but the most accepted hypothesis is reductive dissolution of iron hydroxide $(\mathrm{FeOOH})$, which release the adsorbed arsenic in the aquatic environment (Bhattacharya et al., 2006; McArthur et al., 2004). However identification of source of arsenic is still a matter of study, but some researchers have identified the Himalayan rock as a primary source of arsenic which comes along the river and get deposited in plain areas (Acharyya and Shah, 2007; McArthur et al., 2001). The arsenic enriched groundwater is mainly restricted to the Holocene aquifer at shallow and intermediate depth (Ahmed et al., 2001; Mukherjee and Bhattacharya, 2001). Although arsenic has been extensively studied in West Bengal and Bangladesh but northeastern part of India is also not immune from arsenic contamination. The presence of arsenic has been identified in Assam, Tripura, Arunachal Pradesh, Manipur and Nagaland too (Mukherjee et al., 2006). Assam is an adjoining state of West Bengal with similar hydrogeological pattern. Assam is yet to get attention, though several studies have been done which reported arsenic contamination in the groundwater of 21 districts out of 24 (Singh, 2004; Sailo and Mahanta, 2013).

Remote sensing provides quick and useful information about parameters controlling the occurrence and movement of groundwater like soils, geomorphology, geology, lithology; land use/cover, lineaments etc. (Mukherjee et al., 2005; Todd, 1980). Remote sensing and GIS technology has proved to be an important tool in assessment of geomorphic features. Geomorphology of an area has a significant influence over arsenic enrichment in ground water. Ravenscroft et al. (2001) has shown that the occurrence of arsenic has a close relation to geomorphological units. In the present study, geomorphic features were identified in the Bongaigaon and Goalpara districts of lower Western Assam using satellite images. The groundwater samples were collected from each geomorphic unit and were analyzed to understand the groundwater chemistry and to study the influence of geomorphic features on the mobilization of arsenic in the groundwater of the area.

\section{STUDY AREA}

The study area (Bongaigaon and Goalpara districts) lies in the lower western part of the Assam (Fig.1), and is occupied by both hills and plains. Both districts are situated in the Foreland depression between the comparatively younger mountain chains of the Himalayas in the north and the Block Mountains of Shillong plateau in the south. The geological formations in the 
area are the Archean group of rock comprising BiotiteHornblende gneiss, granulites, schists which are intruded by granite with pegmatites. The area is largely covered with recent alluvial formations composed of sand, gravels, and boulders with occasional clay. The flood plain area (comprises of sand, silt, clay and pebble deposited by the river), piedmont zone, and alluvial sediments of the quaternary age are a good reservoir of groundwater in the area.

The annual rainfall in the state varies between $160 \mathrm{~cm}$ and 430 $\mathrm{cm}$ from place to place The average temperature varies from $4^{\circ} \mathrm{C}$ to $19^{\circ} \mathrm{C}$ during winter and $26^{\circ} \mathrm{C}$ to $37^{\circ} \mathrm{C}$ during summer. The maximum temperature is $33^{\circ} \mathrm{C}$ during July and August, a minimum temperature falls up to $7^{\circ} \mathrm{C}$ in the month of January. The Brahmaputra flows south-westward and then towards west in the Brahmaputra valley. The drainage of the area is controlled by two different systems of rivers. Northerly flowing river system consisting of tributaries (Dudhnoi, Krishnai, Jinjiram, Jinari and Deosila) of the mighty Brahmaputra drains the area towards the east. All the rivers are perennial in nature. Manas, Aie, Champa, Gaurang, Tipkai and Gangadhar are the rivers flowing east to west, also having north-south course in the form of local meanders. To the west of Agia, drainage is controlled by Jinrana river, which flows in westerly direction parallel to the Brahmaputra River. A number of small streams are also present originating from marshy land, and joining to large rivers. The courses of large rivers and marshy tract cover the considerable area of the Goalpara district. Huge load of sediments derived from the Himalayas are responsible for the reduction in the drainage capacity of the river leading to frequent flood during the monsoon season.

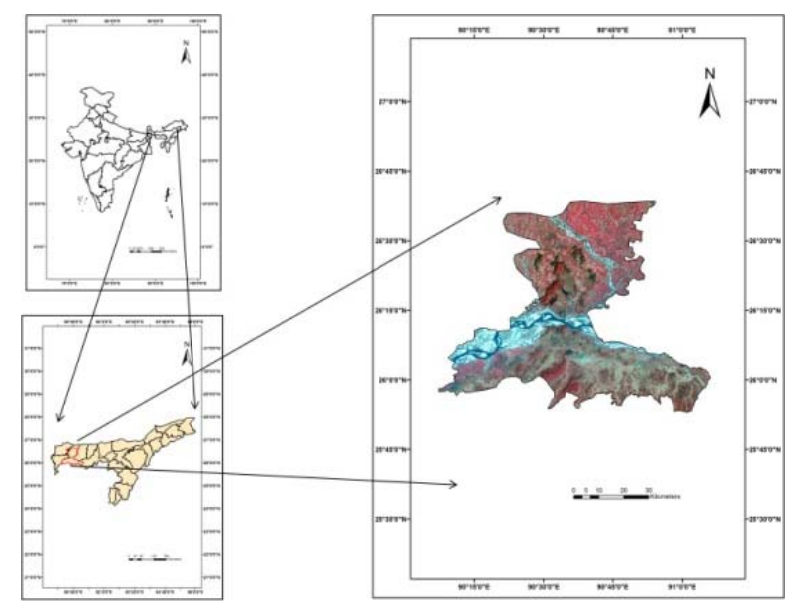

Figure.1. Study area (LISS III satellite image)

\section{MATERIAL AND METHODS}

Landsat images (2006) with spatial resolution 30m of the study area were from USGS website and LISS-III (2006) satellite image with spatial resolution $23.5 \mathrm{~m}$ was obtained from National Remote sensing centre (NRSC) and required image processing was done to the images. Geomorphological units were identified through visual interpretation on the basis of tone, texture, and structure of the features on the multi- date satellite imagery (LISS III/Landsat), and field work was done for ground truthing. Geomorphic features were digitized at 1: 50,000 scale and thematic map was generated by using Arc GIS 10 software. The geomorphic features have been identified at three levels as features and sub-features. Slope map was prepared from Shuttle
Radar Topography Mission data downloaded from the USGS after correcting the images by removing the small imperfections in the data.

Forty-five groundwater samples were collected from each geomorphic unit as inferred on the satellite imagery. Garmin GPS was used to map the location of each sampling sites. Groundwater samples were collected from tube wells and hand pumps of two districts (Bongaigaoun and Goalpara) of Western Assam. Water sample were collected in clean polypropylene bottles (Tarsons). Bottles were rinsed 2-3 times with groundwater to be sampled. During sampling from hand pumps, first few strokes of water were discarded to minimize the impact of the iron content of pipes through which water was pumped out. Samples collected in the bottle $(125 \mathrm{ml})$ were acidified for cations and trace metals analysis and samples collected in 250 $\mathrm{ml}$ bottle was non acidified and used for anion analysis.

$\mathrm{pH}$, electrical conductivity (EC), total dissolved solids (TDS), redox potential $(\mathrm{Eh})$ were measured onsite with the electrode. The samples were stored in styrofoam boxes and then were brought to the laboratory and kept at $4{ }^{\circ} \mathrm{C}$ for further analysis (APHA, 2005). Samples were filtered with $0.45 \mu$ Millipore filter paper using vacuum filtration unit. Bicarbonate and chloride were analyzed using titration method, fluoride using fluoride ion selective electrode, phosphate, sulphate, nitrate and silica were analysed using spectrophotometer (Perkin Elmer Lambda 35) following APHA. Sodium and potassium were analyzed on Flame photometer (Elico flame photometer). Qualitative analysis of calcium, magnesium, iron and arsenic was done using Thermo scientific atomic absorption spectrophotometer (AAS). The saturation of minerals in groundwater measured through Phreeqe software (USGS).

\section{RESULTS AND DISCUSSION}

\subsection{Geomorphology of the area}

The Geomorphological map of the study area was prepared by identifying the various geomorphic units and their components on the basis of tone, texture, shape, size and arrangement of the features. The study area contains mainly fluvial and structural geomorphic features. The geomorphic features of the fluvial origin (alluvial plain, older flood plain and active flood plain) are present in major part of the area while of structural origin (highly, moderately and low dissected hill) are at some of the places. The bar graph of area covered by different geomorphic features (Fig.2) shows that the major part of the study area is covered with older flood plain. The rivers of Assam change their course periodically and the remnant of rivers form paleochannel, backswamp, abandoned channels as prominent landform features of the older flood plain (Fig.3). Features like channel islands, braided bars

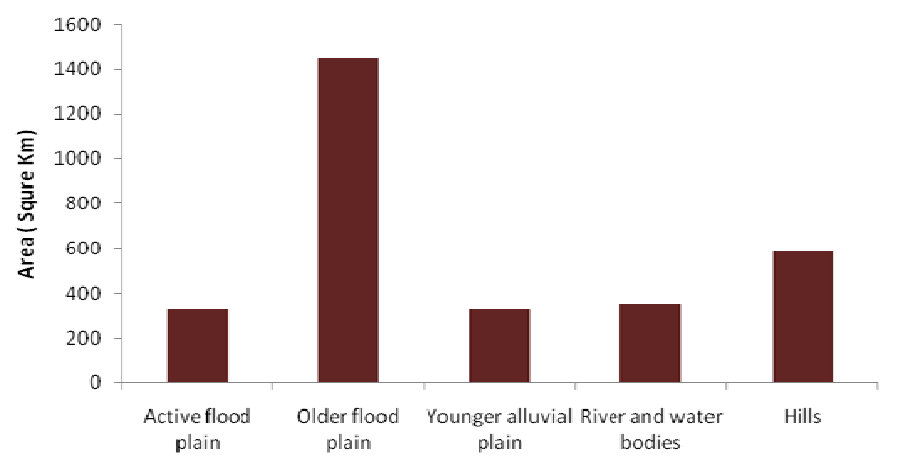

Figure.2. Area covered by different geomorphic features in the study area 
are formed in the regions which frequently experiences flooding and comes under the active flood plain of the area. The Brahamputra basin have the deposition of sediments from the river and their tributaries, with the visible presence of numerous palaeochannels, oxbow lakes, and flood plains.

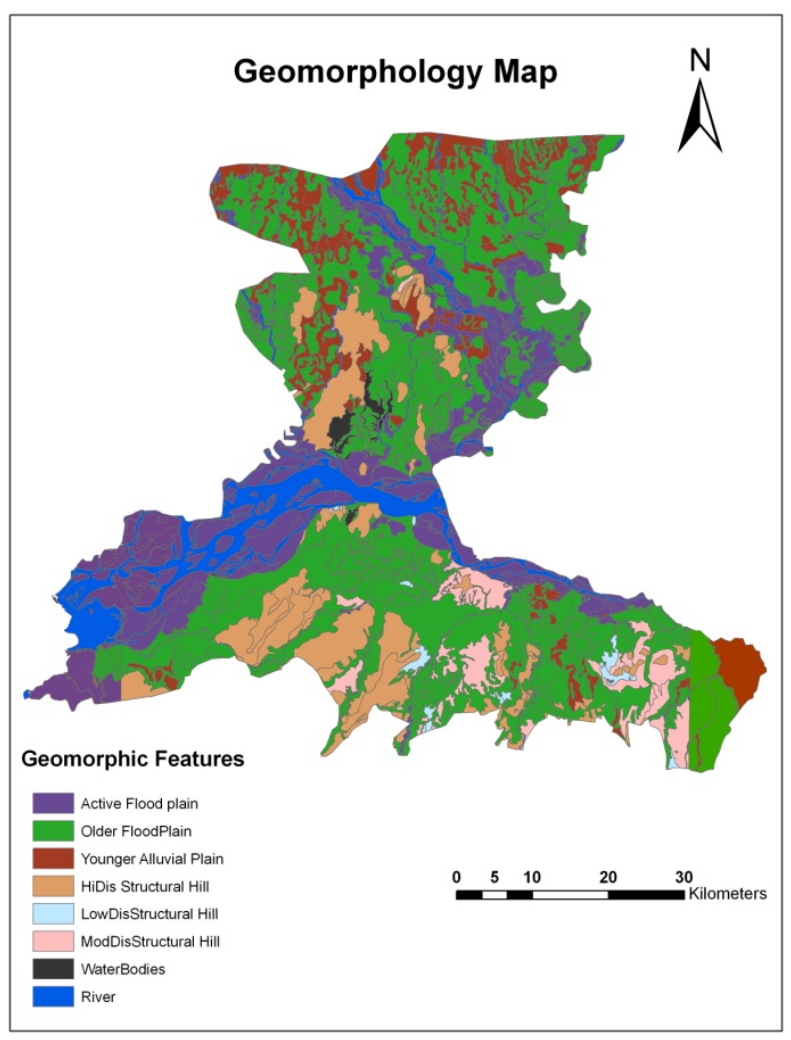

Figure.3. Geomorphology map of the study area

\subsection{Groundwater Chemistry}

The results of the groundwater quality have been tabulated in the form of maximum, minimum and mean (Table 1). $\mathrm{pH}$ of the groundwater in the study area is slightly acidic to alkaline in nature and the value ranges between 6.8 to 8.4 . The electrical conductivity is defined as the ability of a substance to conduct electric current which depends upon dissolution of minerals in the sampled area. The mean value of electrical conductivity in the groundwater samples is $269.7 \pm 64.1 \mu \mathrm{mhos} / \mathrm{cm}$, and TDS value is $188.8 \pm 44.9 \mathrm{mg} / \mathrm{L}$ which indicates that the water samples are mineralized. The results of ground water samples indicate the dominance of cations in the order of $\mathrm{Na}^{+}>\mathrm{Ca}^{2+}>\mathrm{Mg}^{2+}>\mathrm{K}^{+}$while in the anions bicarbonate dominates in the samples followed by chloride, and nitrate $\mathrm{HCO}_{3}{ }^{-}>\mathrm{Cl}^{-}$ $>\mathrm{NO}_{3}{ }^{-}>\mathrm{SO}_{4}{ }^{2-}$

\subsection{Mobilization of arsenic in groundwater}

Out of 45 groundwater samples collected from each geomorphic unit, 8 samples have concentration higher than WHO permissible limit of $10 \mathrm{ppb}$ (Fig.5). The arsenic enrichment is found in the groundwater samples collected from the areas lying along or near the flowing and dry rivers. The geography of study area shows that the area is drained by several rivers from both sides of the Brahmaputra, and arsenic concentration is found to be higher mainly along the river (Manas, Aie) coming from northern Himalayan foothills. (Fig.4) The flood plain sediments drained by the rivers originating from the Himalayan Mountains and Tibetan Plateau are expected to contain arsenic as these are reported to be the geological origin of arsenic in South Asia (Das et al., 2008). The sediments and mineralogy of the basin depend on the type of sediments eroded and transported by the Brahmaputra river and its tributaries. Local geology, geomorphology, hydrogeology, geochemistry of sediments influences the occurrence, origin and mobilization of arsenic in sedimentary aquifers (Bhattacharya et al., 1997; Kinniburgh and Smedley, 2001).

\begin{tabular}{|c|c|c|c|}
\hline Parameters & Max & Min & Mean+Std.dev \\
\hline pH & 8.4 & 6.8 & $7.7 \pm 0.4$ \\
\hline EC & 405 & 146 & $269.7 \pm 64.1$ \\
\hline TDS & 283.8 & 102.6 & $188.8 \pm 44.9$ \\
\hline $\mathrm{Na}^{+}$ & 30.9 & 4.5 & $13.8 \pm 7.3$ \\
\hline $\mathbf{K}^{+}$ & 9.1 & 1.2 & $3.3 \pm 1.5$ \\
\hline $\mathrm{Ca}^{2+}$ & 34.4 & 1.2 & $10.6 \pm 6.3$ \\
\hline $\mathrm{Mg}^{2+}$ & 17.9 & 2.2 & $7.3 \pm 3.6$ \\
\hline $\mathrm{HCO}_{3}^{-}$ & 210.8 & 61 & $118.5 \pm 31.0$ \\
\hline $\mathbf{F}^{-}$ & 3 & 0.1 & $1.1 \pm 0.7$ \\
\hline $\mathrm{Cl}^{-}$ & 36.8 & 7.2 & $15.6 \pm 6.5$ \\
\hline $\mathrm{SO}_{4}{ }^{2-}$ & 3.5 & 0.2 & $1.1 \pm 0.8$ \\
\hline $\mathrm{NO}_{3}{ }^{-}$ & 16.2 & 1.1 & $4.4 \pm 3.2$ \\
\hline $\mathrm{PO}_{4}{ }^{3-}$ & 2.4 & 0.1 & $0.766 \pm 0.5$ \\
\hline $\mathrm{SiO}_{2}$ & 15.4 & 2.3 & $7.8 \pm 3.3$ \\
\hline Fe & 20.9 & 0.1 & $4.3 \pm 4.3$ \\
\hline As (Total) & 20.3 & 0.5 & $3.8 \pm 4.3$ \\
\hline
\end{tabular}

Table 1. All Concentration in $\mathrm{mg} / \mathrm{L}$, except EC $(\mu \mathrm{S} / \mathrm{cm}), \mathrm{pH}$ and As (ppb)

\subsubsection{Variations of Arsenic concentration in different Geomorphic features.}

Enrichment of arsenic in groundwater varies along the geomorphic units in following trends Paleochannel $>$ Younger alluvial plain $>$ Active flood plain $>$ channel island $>$ dissected hills (Table 2). The above trend shows that a higher concentration of arsenic is found in the groundwater samples collected from the fluvial landforms as compared to those collected from structural landforms (Fig.5). The occurrence of arsenic in alluvial plain is usual (Welch et al., 1988) and its enrichment is associated with Holocene sediment brought by rivers originated from Himalayas (Ahamed et al., 2006; Chakraborti et al., 2002; McArthur et al., 2004).

In the present study, it was found that the groundwater samples collected from paleochannel geomorphic features have higher arsenic concentration. Palaeochannels are the remnant geomorphic unit formed through the lateral shift of the rivers. Brahmaputra plain is covered by younger alluvial sediments at most of the places deposited from the sediment load carried by the river and its tributaries (Sarma and Phukan, 2004). The Brahmaputra is a braided stream showing the rapid lateral migration of as much as $800 \mathrm{~m} /$ year (Allison, 1998).

The Brahmaputra river originates from the eastern part of the Mansarovar Lake in the Tibetan Plateau between the Kailash range and the Himalayan range and flows through China, India 
and Bangladesh. The Brahmaputra flows through various rock types, including Precambrian metamorphic rocks, felsic intrusive, Paleozoic-Mesozoic sandstones, shales and limestones of the Himalayan terrain (Sarin et al., 1989; Mukherjee et al., 2009). The northern bank of the river receives sediments derived from the young Himalayas while, south bank from the older Assam plateau (Kunte, 1988). Varied hydrodynamic condition of the river (stream movement and current, sediment load) forms geomorphic features like palaeochannels, abandoned channels, oxbow lakes.

\begin{tabular}{|l|l|l|l|l|}
\hline $\begin{array}{l}\text { Geomorphic } \\
\text { features }\end{array}$ & $\begin{array}{l}\text { Samples } \\
(\mathbf{n}=\mathbf{4 5})\end{array}$ & Max. & Min. & Mean \\
\hline Older flood plain & $\mathbf{1 3}$ & 10.2 & 0.64 & 3.4 \\
\hline Paleochannel & $\mathbf{1 1}$ & 20.9 & 1.1 & 11.7 \\
\hline $\begin{array}{l}\text { Active } \\
\text { Flood Plain }\end{array}$ & $\mathbf{3}$ & 10.43 & 2.12 & 6.7 \\
\hline Channel island & $\mathbf{5}$ & 10.7 & 0.88 & 6.4 \\
\hline $\begin{array}{l}\text { Younger } \\
\text { Alluvial Plain }\end{array}$ & $\mathbf{2}$ & 14.2 & 1.38 & 7.79 \\
\hline $\begin{array}{l}\text { Mod/Highly } \\
\text { dissected hills }\end{array}$ & $\mathbf{1 1}$ & 9.4 & 0.51 & 2.8 \\
\hline
\end{tabular}

Table 2.Arsenic concentration in different geomorphic features

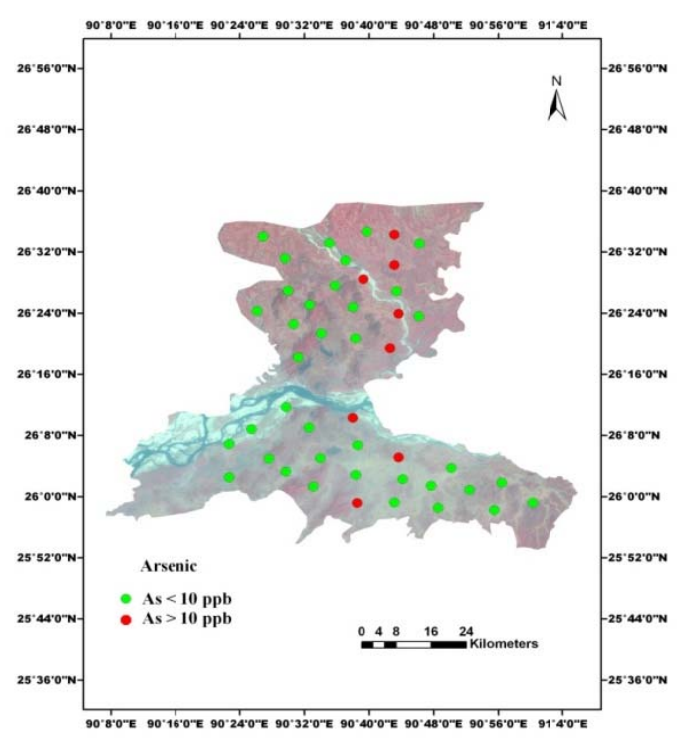

Figure.4. Arsenic contamination in the study area

Large amount of organic matter, fine grained colloidal sized particles get deposited due to swampy condition in the cutoff channel abandoned with the development of large vegetative cover (Shankman, 1991).

The Himalaya was subjected to high erosion and intense rainfall during the Holocene time, thus erosion, oxidation and transportation of arsenic bearing products in solution was high (Gasse et al., 1991). Aquifers containing Holocene sediments are vulnerable to arsenic contamination (McArthur et al., 2011). Arsenic may have been deposited with other fluvial sediments derived from the Himalayas, which has been found in association with insoluble phases like crystalline iron oxides in the river solute load (Stummeyer et al., 2002). Presence of natural and anthropogenically derived organic matter regulates the concentration of arsenic and other trace metals. Low sulfate concentration suggests anoxic condition of the aquifer and may be associated with oxidation of organic matter. Bhattacharya et al., (2002), Clark and Fritz (1997) have shown that the Holocene alluvial sediments are rich in organic matter and create very favourable conditions for reducing bacteria as the aquifers are mostly reducing in nature (Akai et al., 2004).

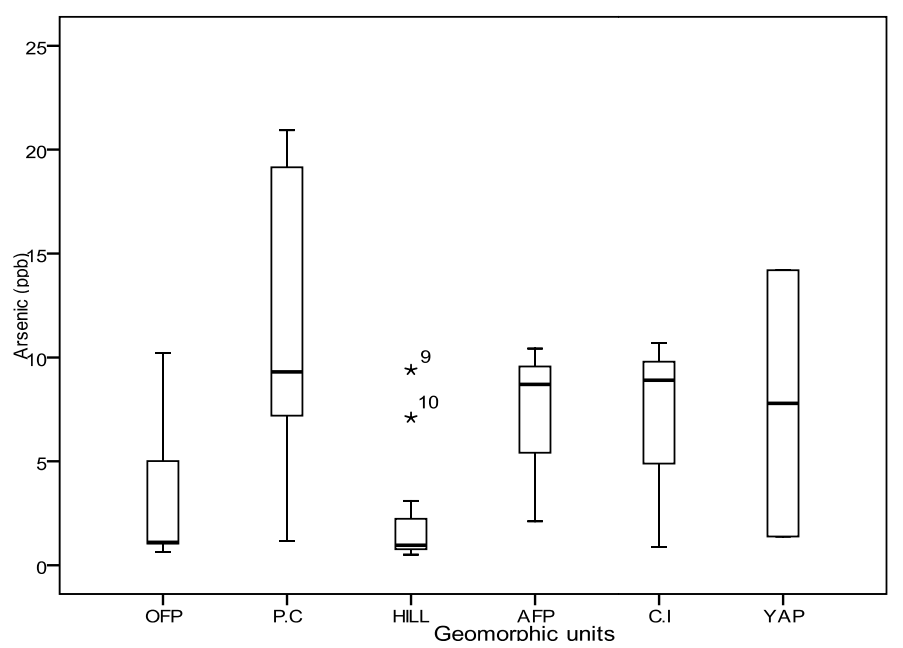

Figure.5. Arsenic contamination in the groundwater samples in different geomorphic units

*(OFP- Older Flood Plain; PC-Paleochannel; AFP- Active Flood Plain; CI- Chanel Island; YAP- Younger Alluvial Plain)

Nature, composition and distribution of organic matter vary along the plain depending on the type of deposition by the river leading to spatio-temporal variability of their reduction process. Bacterially catalyzed oxidative breakdown of these organic matter create the highly anaerobic condition thus facilitating the reductive dissolution of iron oxy hydroxides, thus releasing the sorbed arsenic into the groundwater (Bhattacharya et al. 1997; McArthur et al., 2001). The Reduction potential (Eh) values in palaeochannels are generally low indicating the presence of reducing aquifer in the subsurface (Fig.6). The microbial mediated reductive dissolution of Fe-oxyhydroxides may be responsible for arsenic release in ground water (Islam et al., 2004

$4 \mathrm{FeOOH}+\mathrm{CH}_{2} \mathrm{O}+7 \mathrm{H}_{2} \mathrm{CO}_{3} \rightarrow 4 \mathrm{Fe}^{2+}+8 \mathrm{HCO}_{3}^{-}+6 \mathrm{H}_{2} \mathrm{O}$

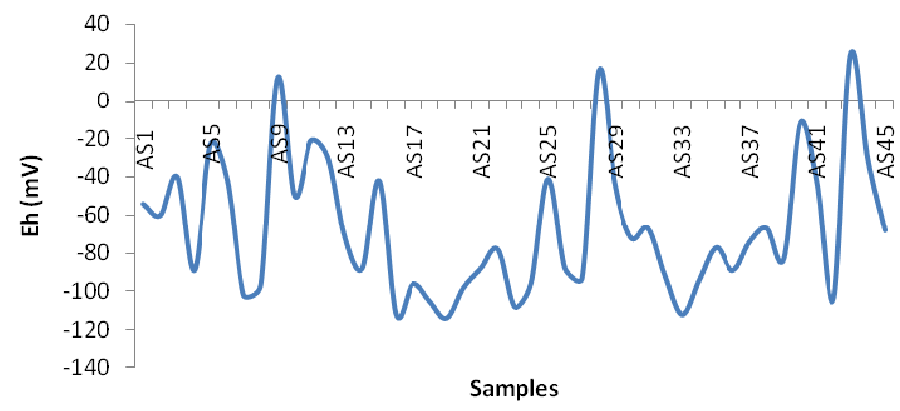

Figure.6. Eh variations in groundwater samples

Arsenic mobilization is mostly controlled by the redoxdependent reactions in the study area as organic matter in the palaeochannels deposited by the river act as the major electron 
acceptor. Decrease in the concentration of nitrate and sulfate in the groundwater samples with an increase in the concentration of bicarbonate (Fig.7) is the evidence of microbially mediated reduction in the presence of organic matter (Halim et al., 2009). Low nitrate and sulfate in the groundwater can be attributed to microbially mediated reduction of organic matter present in the Holocene sediments. The reduction of nitrate and sulfate can be summarized as

$$
\begin{aligned}
& 4 \mathrm{NO}_{3}^{-}+5 \mathrm{CH}_{2} \mathrm{O} \rightarrow 2 \mathrm{~N}_{2}+5 \mathrm{HCO}_{3}^{-} \\
& \mathrm{SO}_{4}^{2-}+2 \mathrm{CH}_{2} \mathrm{O} \rightarrow 2 \mathrm{H}_{2} \mathrm{~S}+2 \mathrm{HCO}_{3}^{-}
\end{aligned}
$$

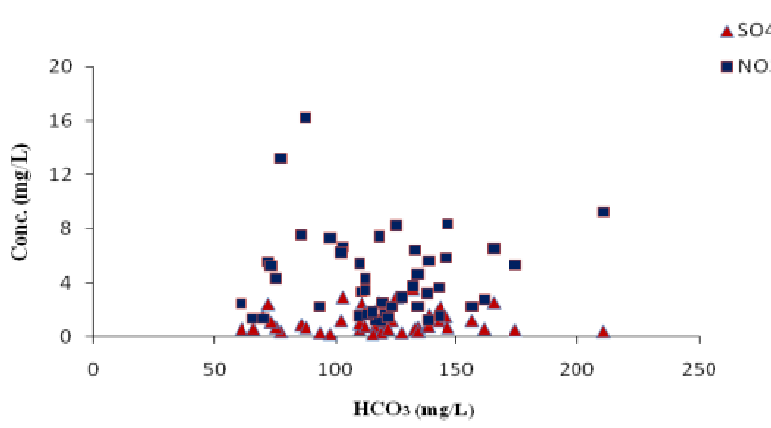

Figure. 7. Scatter plot of concentration of Sulphate and Nitrate against Bicarbonate

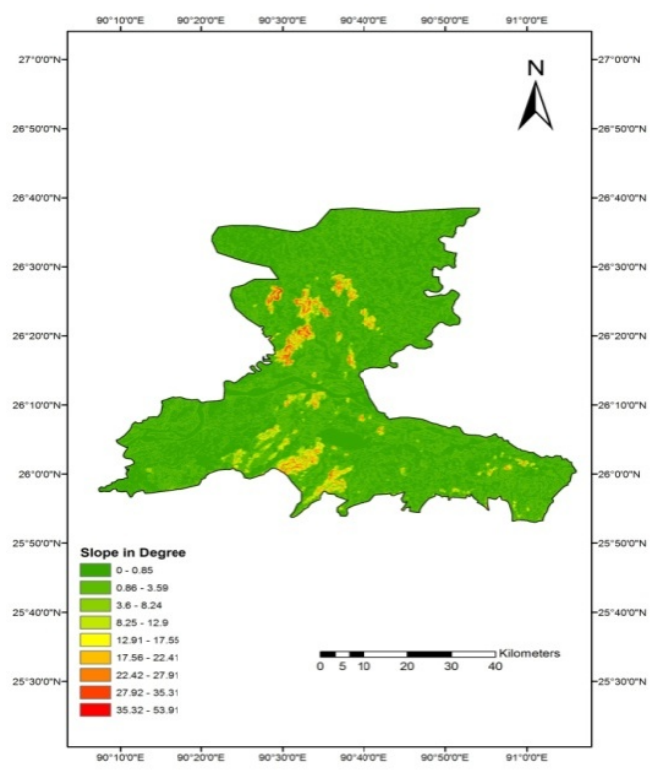

Figure.8. Slope in the study area

Slope map (Fig.8) shows that the slope of the study area ranges between 0 to $53.9^{\circ}$. The area is mostly occupied by alluvial plain where slope is very less varying between 0 to $8.2^{\circ}$, while in hilly area which lies at both the bank of Brahmaputra river, slope varies from low $\left(8.2^{\circ}-12.9^{\circ}\right)$, moderate $\left(17.5^{\circ}-22.4^{\circ}\right)$ to very steep $\left(27.9^{\circ}-53.9^{\circ}\right)$. Slope has an influence over surface runoff and infiltration and determines the groundwater availability and quality in an area. Flat terrain of the area with very less slope provide the surface water in these geomorphic features enough time to infiltrate deep into the aquifer, thus providing the pathway for the contaminant to reach into the groundwater.
Since fluvial geomorphic units contain higher organic matter and easily undergoes microbial reduction, the above processes may be responsible for the enrichment of arsenic in the concerned aquifer (Enmark and Nordborg, 2007). Although arsenic is mobilized through reductive dissolution of $\mathrm{Fe}-$ oxyhydroxides but existing data does not show any correlation between iron and arsenic (Fig.9). This may be possible because iron which is non conservatory may be involved in other reactions and precipitates as siderite (Welch and Lico, 1998; Sailo and Mahanta, 2013).

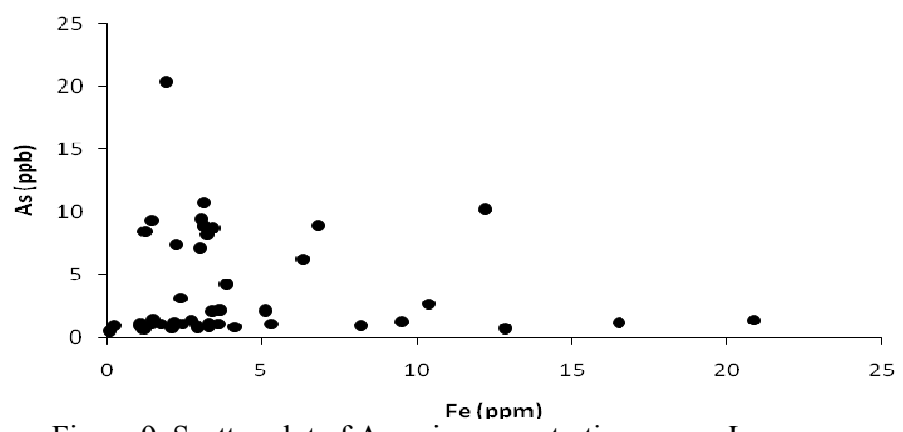

Figure.9. Scatter plot of Arsenic concentration versus Iron

The mineral saturation indices on the basis of hydrochemical data in the groundwater samples have been determined through Phreeqe software (USGS) by using the following formula

$$
\mathrm{SI}=\log (\mathrm{IAP} / \mathrm{Kt})
$$

Where, IAP $=$ Ion activity product of the dissociated mineral. $\mathrm{Kt}=$ equilibrium solubility constant.

$\mathrm{SI}<0$ indicates undersaturation, and $>1$ reflects supersaturation of groundwater with respect to particular mineral.

The results of mineral saturation show the high degree of undersaturation of halite and $\mathrm{CO}_{2}(\mathrm{~g})$ in groundwater while siderite, dolomite, calcite, and quartz shows a good degree of saturation in groundwater samples collected (Fig.10).

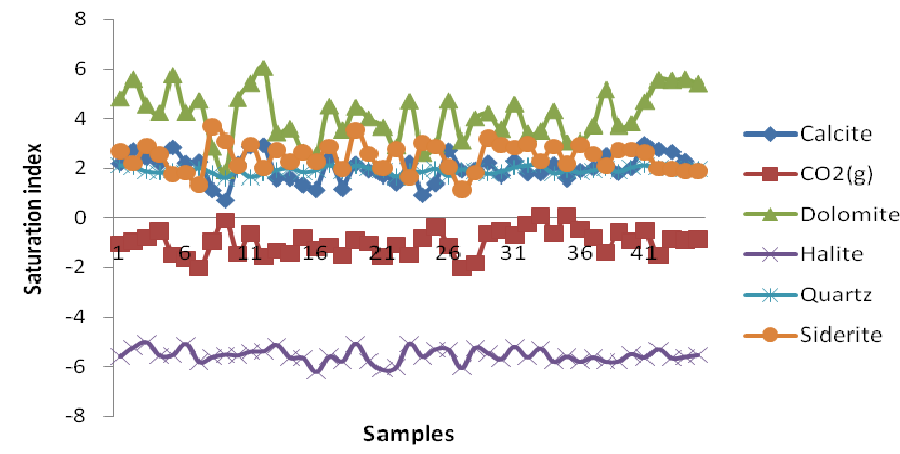

Figure.10. Saturation Indices of groundwater

Arsenic enriched groundwater is supersaturated with siderite and presence of iron reducing bacteria facilitates the precipitation of iron as siderite (Saunders and Swann, 1992).

$$
\mathrm{Fe}^{2+}+2 \mathrm{HCO}_{3}^{-} \rightarrow \mathrm{FeCO}_{3}(\text { siderite })+2 \mathrm{H}^{+}
$$

Precipitation of siderite will remove iron relative to arsenic in groundwater (Dowling et al., 2002), This penhamena have explained the poor statistical correlation for iron and arsenic in groundwater.

\section{Conclusions}


The groundwater collected from geomorphic units were slightly acidic to alkaline in nature with most of the parameters well within the permissible limit of WHO except for fluoride, iron and arsenic. Arsenic concentration was found to be higher in the samples collected from the fluvial geomorphic features especially palaeochannels. Geomorphological map prepared from the satellite images shows that most part of the area is covered with geomorphic features of fluvial origin formed by the rivers. River Brahmaputra and their tributaries often change their course periodically thus creating palaeochannels, oxbow lakes, channel islands as major geomorphic units. During the lateral shift of the river, lot of minerals, sediments and organic matter get deposited into these geomorphic units. Over a period of time, microbial degradation of these organic matters create reducing environment which is evident from negative redox potential in the study area. A low Eh brought on by the degradation of organic matter may be responsible for the dissolution of the iron hydroxide present in the sediments leading to the desorption of any adsorbed arsenic. Slope map shows the flat terrain of the area with a very less slope which facilitates the infiltration of the stored water deep into the aquifer. In the present study, authors found that reductive dissolution of iron hydroxide is the main source of arsenic release into the groundwater. The arsenic may have been present in adsorbed from with the minerals deposited in sediments carried from the Himalayas. Poor correlation between arsenic and iron may be due to the precipitation of iron as siderite.

\section{Acknowledgements}

Authors thanks to Council of Scientific and Industrial Research (CSIR) for providing fellowship to pursue research work. Authors also acknowledge to Jawaharlal Nehru University for providing instrument facilities to analyse the water samples.

\section{References}

Acharyya, S.K., Shah, B.A., 2007. Groundwater arsenic contamination affecting different geologic domains in India-a review: influence of geological setting, fluvial geomorphology and Quaternary stratigraphy. Journal of Environmental Science and Health Part A 42, 1795-1805.

Ahamed, S., Sengupta, M.K., Mukherjee, A., Hossain, M.A., Das, B., Nayak, B., Pal, A., Mukherjee, S.C., Pati, S., Chatterjee, R.N.D.G., Mukherjee, A., Srivastava, R., Chakraborti, D., 2006. Arsenic groundwater contamination and its health effects in the state of Uttar Pradesh (UP) in upper and middle Ganga plain, India: A severe danger. Science of the Total Environment $370 \mathrm{v}$.

Ahmed, K.M., Imam, M.B., Akhter, S.H., Hasan, M.A., Khan, A.A., 2001. Sedimentology and mineralogy of arsenic contaminated aquifers in the Bengal Delta of Bangladesh. In: Jacks, G., Bhattacharya, P. and Khan, A.A. ed., Groundwater Arsenic Contamination in the Bengal Delta Plain of Bangladesh. Proc. KTH-Dhaka University Seminar. KTH Special Publication, TRITA-AMI Report 3084, 97-108.

Akai, J., Izumi, K., Fukuhara, H., Masuda, H., Nakano, H., Yoshimura, T., Ohfuji, H., Anawer, M.H., Akai, K., 2004. Mineralogical and geomicrobiological investigations on groundwater arsenic enrichment in Bangladesh. Applied Geochemistry 19, 215-230.

Allison, M.A., 1998. Geologic framework and environmental status of the Ganges- Brahmaputra delta. Journal of Coastal Research 14 (3), 826-836.

APHA (2005) Standard methods for the examination of water and waste water, 21st edn. American Public Health Association, Washington.
Berg, M., Tran, H.C., Nguyen, T.C., Schertenleib, R., Giger, W., 2001. As contamination of groundwater and drinking water in Vietnam: a human health threat. Environmental Science and Technology 35, 2621-2626.

Bhattacharya, P., Ahmed, K.M., Hasan, M.A., Broms, S., Fogelström, J., Jacks, G., Sracek, O., Brömssen, M., Routh, J., 2006. Mobility of arsenic in groundwater in a part of Brahmanbaria district, NE Bangladesh. In: Naidu R, Smith E, Owens G, Bhattacharya P, Nadebaum P (eds) Managing arsenic in the environment: from soil to human health. CSIRP Publishing, Melbourne, 95-115 pp.

Bhattacharya, P., Chatterjee, D., Jacks, G., 1997. Occurrence of arsenic-contaminated groundwater in alluvial aquifers from Delta Plain, Eastern India: options for a safe drinking water supply. Water Resources Development 13, 79-92.

Bhattacharya, P., Jacks, G., Ahmed, K.M., Khan, A.A., Routh, J., 2002. Arsenic in groundwater of the Bengal Delta Plain aquifers in Bangladesh. Bulletin of Environmental Contamination and Toxicology 69, 538-545.

Chakraborti, D., Das, D., Samanta, B.K., Mandal, B.K., Chowdhury, T,R., Chanda, C.R., Chowdhury, P.P., Basu, G.K., 1996. Arsenic in groundwater in six districts of West Bengal, India. Environmental Geochemistry and Health 18, 5-15.

Chakraborti, D., Rahman, M. M., Chowdhury, U. K., Paul, K., Sengupta, M. K., Lodh, D., 2002. Arsenic calamity in the Indian subcontinent: what lessons have been learned? Talanta 59, 322.

Chowdhury, T.R., Basu, G.K., Mandal, B.K., Biswas, B.K., Samanta, G., Chowdhury, U.K., Chanda, C.R., Lodh, D., Roy, S.L., Saha, K.C., Roy, S., Kabir, S., Quamruzzaman, Q., Chakraborti, D., 1999. Arsenic poisoning in the Ganges Delta. Nature 401, 545-546.

Clark, I., Fritz, P., 1997. Environmental Isotopes in Hydrology, Lewis, Boca Raton, NY.

Das, A.J., Battles, J.J., van Mantgem, P.J., Stephenson, N.L., 2008. Spatial elements of mortality risk in old-growth forests. Ecology 89, 1744-1756.

Das, D., Samanta, G., Mandal, B.K., Chowdhury, T.R., Chanda, Ch.R., Chowdhury, P.P., Basu, G.K., Chakraboti, D., 1996. Arsenic in groundwater in six districts of West Bengal, India. Environmental Geochemistry and Health 18, 5-15.

Dowling, C.B., Poreda, R.J., Basu, A.R., Peters, S.L., 2002. Geochemical study of arsenic release mechanisms in the Bengal Basin groundwaters. Water Resource Researches 38: 11731190.

Enmark, G., Nordborg, D., 2007. Arsenic in the groundwater of the Brahmaputra floodplains, Assam, India- Source, distribution and release mechanisms. Minor Field Study 131, Committee of Tropical Ecology, Uppsala University, Uppsala, Sweden, 35pp. Gasse, F., Arnold, M., Fontes, J.C., Fort, M., Bingyan, L., Quinsang, Z., 1991. A 13,000 year record from western Tibet. Nature 353, 742-745.

Gaus I, Kinniburgh DG, Talbot JC, Webster R 2003. Geostatistical analysis of As concentration in groundwater in Bangladesh using disjunctive kriging. Environ Geol 44:939-948 Gurung, J.K., Ishiga, H., Khadka, M.S., 2005. Geological and geochemical examination of As contamination in groundwater in the Holocene Terai Basin, Nepal. Environmental Geology 49, 98-113.

Halim M.A., Majumder, R.K., Nessa, S.A., Hiroshiro, Y., Uddin, M.J., Shimada, J., Jinno, K., (2009) Hydrogeochemistry and arsenic contamination of groundwater in the Ganges Delta Plain, Bangladesh. Journal of Hazardous Materials 164, 13351345.

Islam, F.S., Gault, A.G., Boothman, C., Polya, D.A., Charnock, J.M., Chatterjee, D., Lloyd, J. R., 2004. Role of metal reducing 
bacteria in arsenic release from Bengal delta sediments. Nature 430, 68-71.

Khan, S.D., Mahmood, K., Sultan, M.I., Khan, A.S., Xiong, Y., 2010. Trace element geochemistry of groundwater from Quetta Valley, western Pakistan. Environmental Earth Science 60, 573-582.

Kinniburgh, D.G., Smedley, P.L., 2001. As Contamination of Groundwater in Bangladesh. British Geological Survey Report, WC/00/19, Dhaka.

Kunte, S.V., 1988. Geomorphic analysis of upper Assam plains and adjoining areas for hydrocarbon exploration. Jornal of Indian Society of Remote Sensing 16, 15-28.

McArthur M., Banerjee, D.M, Hudson-Edwards, K.A., Mishra, R., Purohit, R., Ravenscroft, P., Cronin, A., Howarth, R.J., Chatterjee, A., Talukder, T., Lowry, D., Houghton, S., Chadha, D.K., 2004. Natural organic matter in sedimentary basins and its relation to arsenic in anoxic ground water: the example of West Bengal and its worldwide implications. Applied Geochemistry 19, 1255-1293.

McArthur, J.M., Nath, B., Banerjee, D.M., Purohit, R., Grassineau, N., 2011. Palaeosol control on groundwater flow and pollutant distribution: the example of arsenic. Environmetal Science and Technology 45, 1376-1383.

McArthur, J.W., Ravenscroft, P., Safiullah, S., Thirlwall, M.F., 2001. Arsenic in groundwater: testing pollution mechanisms for sedimentary aquifers in Bangladesh. Water Resources Research 37, 109-117.

Mukherhee, A, Fryar, A.E., Thomas, W.A., 2009. Geologic, geomorphic, and hydrologic framework and evaluation of the Bengal basin, India and Bangladesh. Journal of Asian Earth Sciences 34, 227-244

Mukherjee, A.B., Bhattacharya, P., 2001. Arsenic in groundwater in the Bengal Delta Plain: slow poisoning in Bangladesh. Environmental Reviews 9, 189-220.

Mukherjee, A., Sengupta, M.K., Hossain, M.A., Ahmed, S., Das, B., Nayak, B., Lodh, D., Rahman, M.M., Chakraborti, D., 2006. Arsenic contamination in groundwater: a global perspective with emphasis on the Asian scenario. Journal of Health Population and Nutrition 24, 142163.

Mukherjee, S., Kumar, B.A., Kortvelyessy, L., 2005. Assessment of Groundwater Quality in the South 24 Parganas, West Bengal Coast, India. Journal of Environmental Hydrology 13(15), 1-8.

Mukherjee, S.C., Saha, K.C., Pati, S., Dutta, R.N., Rahman, M.M., Sengupta, M. K., 2005. Murshidabad-one of the nine groundwater arsenic affected districts of West Bengal India. Part II: dermatological neurological and obstetric findings. Clinical Toxicology 43, 835-848.

Nickson, R., McArthur, J., Ravenscroft, P., Burgess, W., Ahmed, K.M., 2000. Mechanism of arsenic release to groundwater, Bangladesh and West Bengal. Applied Geochemistry 15, 403-413.

Polya, D.A., Gault, A.G., Diebe, N., Feldman, P., Rosenboom, J.W., Gilligan, E., Fredericks, D., Milton, A.H., Sampson, M., Rowland, H.A.L., Lythgoe, P.R., Jones, J.C., Middleton, C., Cooke, D.A., 2005. As hazard in shallow Cambodian groundwater. Mineralogical Magazine 69, 807-823.

Ravenscroft, P., McArthur, J.M., Hoque, B.A., 2001. Geochemical and palaeohydrological controls on pollution of groundwater by arsenic. In: W. R. Chappell, C. O. Abernathy, R. L. Calderon 4th International Conference on Arsenic Exposure and Health Effects, Elsevier Oxford, in press.

Sailo, L., Mahanta, C., 2013. Hydrogeochemical factors affecting the mobilization of arsenic into the groundwater of the Brahmaputra alluvial plains of Assam, Northeast India. Environmental Science Processes Impacts 15, 1775-1782.
Sarin, M.M., Krishnaswamy, S., Dilli, K., Somayajulu, B.L.K., Moore, W.S., 1989. Major ion chemistry of the GangaBrahmaputra river system: Weathering process and fluxes to the Bay of Bengal. Geochim et Cosmochimica Acta 53, 997-1009. Sarma, J.N., Phukan, M.K., 2004. Origin and some geomorphological changes of Majuli Island of the Brahmaputra River in Assam, India. Geomorphology 60, 1- 19.

Saunders, J.A., and Swan, C.T., 1992. Nature and origin of authigenic rhodochrosite and siderite from the Palaozoic aquifer, northeast Mississippi, U.S.A. Applied Geochemistry 7, 375-387.

Shankman, D., 1991. Forest regeneration on abandoned meanders of a coastal plain river in western Tennessee. Castanea 56, 157-167.

Singh, A.K., 2004. Arsenic contamination in groundwater of Northeastern India. In Proceedings of 11th national symposium on hydrology with focal theme on water quality. Roorkee: National Institute of Hydrology, 255-262 pp.

Stummeyer, J., Marchig, V., Knabe, W., 2002. The composition of suspended matter from Ganges-Brahmaputra sediment dispersal system during low sediment transport season. Chemical Geology 185, 125-147.

Todd, D.K., 1980. Groundwater Hydrology, $2^{\text {nd }}$ edition. John Wiley \& Sons, New York, 111-163pp.

Welch, A.H., Lico, M.S., 1998. Factors controlling As and U in shallow groundwater, southern Carson Desert, Nevada. Journal of Applied Geochemistry 13, 521-539.

Welch, A.H., Lico, M.S., Hughes, J.L., 1988. Arsenic in ground water of the western United States. Ground Water 26(3), 333347. 